ESJ Humanities

\title{
The Effect of Church Conflict on the Growth of Pentecostal Churches in Kenya: A Case Study of Selected Churches in Nairobi
}

\author{
John Miatu Thiga \\ Lecturer, PAC University, Nairobi \\ Africa International University, Nairobi, Kenya \\ Prof. Gyang D. Pam, PhD
}

H.O.D. Theology, Africa International University, Nairobi, Kenya

Prof. James Nkansah-Obrempong, PhD

Dean School of Theology, Africa International University, Nairobi, Kenya

Doi:10.19044/esj.2021.v17n16p22

Submitted: 02 April 2021

Accepted: 11 May 2021

Published: 31 May 2021
Copyright 2021 Author(s)

Under Creative Commons BY-NC-ND

4.0 OPEN ACCESS

Cite As:

Thiga J.M., Pam G.D. \& Nkansah-Obrempong J. (2021). The Effect of Church Conflict on the Growth of Pentecostal Churches in Kenya: A Case Study of Selected Churches in Nairobi. European Scientific Journal, ESJ, 17(16), 22. https://doi.org/10.19044/esj.2021.v17n16p22

\begin{abstract}
The purpose of the study was to determine the effect of church conflict on the growth of Pentecostal churches in Kenya with focus on selected churches in Nairobi which are struggling with growth. The objectives of the study were to investigate the nature of conflicts in the Pentecostal churches in Kenya, determine the effect of conflict on the growth of Pentecostal churches in Kenya, and to assess the conflict resolution mechanisms employed to solve the conflict in Pentecostal churches in Kenya. The study was carried out in branches of four churches which experienced growth challenges, namely: Full Gospel Churches of Kenya, Kenya Assemblies of God, Pentecostal Evangelism Fellowship of Africa, and Worldwide Gospel Church of Kenya. The study used qualitative research approach as it intended to collect data based on participants' subjective experience, and its ability to uncover unexpected and exploring new avenues. The target population was church leaders who have been in the church for at least two years. The study used purposive sampling method to select the church leaders in influential positions (i.e., leaders that direct and/or lead a church ministry) of the selected churches
\end{abstract}


according to the church leadership structure espoused by each of the four selected churches. Proportionate stratified sampling was used where equal number of units was selected from each stratum. Data was collected using face-to-face individual interview schedule. The data was analyzed thematically using content analysis method. The researcher came up with the vital themes, recurring ideas, and patterns of belief, which assisted with the integration of the results. The study found that there were conflicts in all the churches under study. The study established that there were top leadership wrangles at the national level seeking to control the church. There were also local church leadership wrangles pitting pastors and other leaders and conflict among other leaders within the church. The study established that conflict negatively affected the growth of the church as the churches lost members to other churches around. Among the conflict resolution mechanism used were prayer and fasting, dialogues, and courts. The study recommends that the Pentecostal churches should adopt conflict resolution methods and avoid conflicts by practicing inclusivity.

Keywords: Pentecostal churches, conflicts, conflict resolution, church growth

\section{Introduction}

\section{Background of the Study}

Pentecostalism, touted as a universal phenomenon, has attracted theologians especially those who focus on missiology. This has prompted investigations and analysis of its growth and effects. Pentecostalism is argued to be fast growing in our contemporary world (Atoyebi, 2010). It has been found to have large followings in Northern part of America, South America, the Asian world, Africa, and the world at large (Asamoah-Gyadu, 2007, p.128; Anderson, 2013). Andersons (2013) notes that Pentecostalism is not only acknowledged as a global movement but has emerged as a third world or nonwestern movement particularly because a massive growth has been witnessed in Africa.

In Africa, the wide spread of Pentecostalism is attributed to the fact that it is inclined to strive to connect with the unseen spiritual world, which resonates well with many African beliefs and practices. Atoyebi (2010) listed the reasons which contributed to the spread of Pentecostal churches in Africa to include: (1) 'Flexibility of the spirit', it is easily transplanted to any cultural context; (2) Manifestation of the Holy Ghost, especially in deliverance which was not limited to sin alone but also from demonic possession and attacks, poverty and healing and promises of prosperity; and (3) spontaneity and communal participation in worship.

In Kenya, the growth rate of Pentecostal churches can be termed as remarkable since the 1970s, surpassing those of the mainstream churches like 
the Catholic and Anglican churches (Gathuki, 2015). As Parsitau and Mwaura (2010) put it, Pentecostalism has become a prominent feature both in the religious and political landscape of the country and urban areas in particular. According to the Pew Forum on Religion and Public Life Survey, Pentecostals or the charismatic movements constitute a big number, which may add up to half the population in Kenya (PFRPL, 2006). Pentecostal churches are found operating at any empty space including classrooms, uncompleted buildings, garages, in the open fields and so on (Jando, 2014).

However, a scrutiny reveals that growth has not been significant (Lamb, 2016). Church growth has been on the decline trend in both developed and developing countries (Parsitau, 2014). In Germany, for instance, the church ministry has been described as being in crisis, as majority are experiencing decline in membership with only a few recording growth (Olson, 2008). In America, the influence of Christianity is waning, creating an emergency as cultural conditions and shallow believers combine to create what Olson (2008) calls "the American church crisis." The decline has been recorded in the areas of church attendance as only $17.5 \%$ of the US population is attending Sunday church services (Olson 2008), prayers, religious affiliation, bible study, and generally belief in God for decades.

In Kenya, things have not been different. While other churches have continued to experience growth from a humble beginning and rising to be counted among the big churches, such as the Jubilee Christian Church with over 8,000 memberships and The Mavuno Church with a membership of over 2,000 members, several other Pentecostal churches in the urban centers in Kenya are experiencing growth challenges (Atoyebi, 2010). The Kenya Assembly of God, for instance, saw its Karen branch close in 2008 after gradual decline of its congregation to extinction (Shaw \& Gitau, 2016). Shaw and Gitau also pointed out that the Calvary Worship Centre has struggled with a total membership of only 150 members for long.

Many factors have been found to affect the Pentecostal church growth particularly in the urban areas. For instance, Rasool, et al. (2015) noted that the Pastor's leadership style influenced the church growth. Masamba (2013) stated that church growth was also affected by the pastor's theological training. Another factor affecting the church growth and which is the focus of this study is the church conflict. One unique notable feature from the beginning is that Pentecostal churches were always involved in conflicts (Gathuki, 2015).

The church like every other society encounters internal crisis (Folarin \& Adelakun, 2016). Ogunbameru (2008, p.33) defines conflict as the confrontation of powers. Conflict is a state of opposition, clash, collision, antagonism, and discord. Conflict in church is as old as the early church when in Corinth the believers argued over Paul and Apollos (I Corinthians 3:4). 
According to Onyima (2013), conflict has been endemic in Christian religious institutions and the Pentecostal church in particular. Hollenweger (1997) notes that conflict among the Pentecostals began in 1906 with Charles Price Jones and Charles Harrison Mason who were both pastors in the "Church of God in Christ", a Pentecostal church located in a cotton gin in California. Pentecostalism has experienced a variety of divisions and controversies which have hampered its growth both numerically and spiritually (Wilfred, 2011). According to Gathuki (2015) and Kamau (1994), church conflict among the Pentecostal churches has resulted to splits and disagreements. The church has lost some of its members to other churches or some have simply left the faith and have gone back to the lives they once lived before salvation (Gathuki, 2015).

\section{Statement of the Problem}

Despite the establishment and growth of Pentecostal churches in Kenya, they are riddled with conflict which has had a negative impact on their growth. For instance, Kamau (1994) asserts that there are many cases of conflicts in Pentecostal churches, usually followed by splits. In 2008, for instance, the Full Gospel Churches of Kenya (FGCK) was involved in a succession of dispute which resulted to a split. In 2000, similar conflicts had split the Gospel Outreach Church of Kenya forming a new faction called Gospel Revival Centre (GRC). In 2014, the Deliverance Church Nyeri branch got involved in leadership conflicts which caused a split. During these conflicts and splits, there is loss of membership either to the warring faction or to the other churches or just members being unaccounted for. As such, these churches remain stunted in terms of numerical growth as every time there is growth, a conflict arises leading to loss of members as was noted by Gathuki (2015). It is upon this backdrop that the current study embarks on investigating the growth challenges of the Pentecostal churches in urban Kenya.

\section{Significance of the Study}

This study has three-fold scientific relevance. First, the study would benefit Christian leaders in Kenya as they will get to understand how church conflict was influencing the growth of Pentecostal churches in urban centers in Kenya and probably take action to address the challenges Secondly, the study will help Pentecostal church members to gain understanding on the impact of conflict to Church growth and development. It will also essentially demonstrate the importance of unity, peace, and love among Christians. Thirdly, the study has academic relevance as it contributes to a body of knowledge on the impact of conflict to the Church. 


\section{Literature Review Overview of Pentecostalism}

Pentecostalism is a major driving force behind the transformation in Christianity. The movement dates back to the first Century when disciples of Jesus were first filled with the Holy Spirit in the Upper Room for the first time and spoke in other tongues, prophesied, healed the sick, and the beginning of the spreading of the church to Asia Minor (see Acts 2) (Dayton, 1987). The modern-day Pentecostalism can be traced to January 1901 in Topeka Kansas when Bethel Bible School students under the tutelage of Charles F. Parham spoke in other tongues (Parsitau, 2014). Parsitau (2014) further notes that Parham later took this message of the baptism of the Holy Spirit to his friend, a black Holiness preacher William J. Seymour in Houston, who became convinced that the Holy Spirit was still working miracles. Preaching to a small gathering of people in 1906 in Los Angeles, Seymour ignited the Azusa Street Revival where the interracial gathering began to do as the first Century apostles, speaking in tongues, healing, and prophesying (Anderson, 2004; Synan, 2001; Burgess \& Van-der-Maas, 2002; Adogame, 2010).

Within a short period of time, Pentecostal missionaries went to all parts of the world and this marked the launch of the Pentecostal movement (Anderson, 2013). However, similar manifestations had been witnessed in the $20^{\text {th }}$ Century in England, Finland, Russia, Latin America, India, and Africa (Anderson, 2004, 2013). Within a few years of the aforementioned 1906 upsurge, Pentecostalism had in fact established itself worldwide. By the beginning of the twenty-first century, it had expanded to various nations (Anderson, 2002). Today, majority of Pentecostal believers are found in Nonwestern countries, especially in the Global South. The PFRPL (2006) survey, which has analyzed the religious demography of ten countries including Nigeria, Kenya, and South Africa, has demonstrated how Africa, alongside with Asia and Latin America, are becoming significant global players in the democratization and appropriation of world Christianity (Adogame, 2010).

In Africa, Pentecostalism can be traced to more than a century ago. Hollenweger (1997) observes that Pentecostalism in Africa began with John Graham Lake who lived between 1870 and 1935. Graham led a large missionary party to Johannesburg South Africa in April 1908 marking the beginning of the spread of Pentecostalism in Africa. He founded the Apostolic Faith Mission of South Africa (AFMSA) in 1910 and the Zion Christian Church (ZCC) in 1913. These two were large and influential Pentecostal churches in South Africa. The missionary Pentecostal churches in the subSaharan Africa were mainly established in the first half of the twentieth century (Kay, 2008; Kalu, 2008). Particularly, the Assemblies of God has recorded tremendous growth in majority of the countries with the African population put to more than four million in 1994 (Wilson, 2006). 
Parsitau (2014) notes that from 1980, many Pentecostal churches and ministries have come up in Kenya. Some were founded locally and others were founded by international ministers from Europe, America, Asia and even Africa, mainly Nigeria. Among the evangelists who visited Nairobi and major towns are Morris Cerullo, Reinhard Bonnke, Benny Hinn, and Emmanuel Eni among others. These preachers did not have denominational boundaries, but they claimed to have charismatic powers to preach, spiritual gifts, and faith for healing. Their emphasis was spiritual renewal and numerical expansion.

\section{Overview of Church Growth}

McGavran defined church growth as "the planting and care of selfpropagating churches" (McGavran, 1970). His view of church growth was championed by the Church Growth Movement (CGM), which he founded in 1955 (cf. Wagner, 1981). The theological assumption of the movement is that people need to hear and receive the Gospel in order to be saved (1 John 5:12). McGavran thus defined the notion and principle of church growth by placing evangelism as the top priority of the mission of the church. However, this is not sterile evangelism of 'search theology' without addition to numbers of the saved. Evangelism, within the concept of church growth and by CGM, is only valid when it leads individuals to becoming committed to Jesus Christ as Saviour and to His church as a responsible member (Wagner, 1981, p.57). Therefore, this is the evangelistic mandate that defines the existence of the church growth movement and serves as impetus to the definitions of church growth promoted by its members.

The concept of Church growth is sometimes used in referring to the quantitative and qualitative growth of the Church. At other times, it is used to denote a discipline; and it can also be used to mean a movement (Bontrager \& Showalter, 2006). In the biblical context, church growth reporting was not counted in the same manner as doing research or publication. It was done in the form of letters and historical reports (Sisemore, 2009). Mostly, the church growth is founded and recorded in the book of Acts with some mentioned in the epistles, which somehow describe the growing of churches like the churches in Philippi, Corinth, Ephesus, Colossae, and Thessalonica. In Acts 1:15 and Acts 2:41, church growth is mentioned in terms of numerical growth. In Acts 4:43 and Acts 4: 23-30, it is described as spiritual growth. The Bible records that as they continued meeting and praying together, the Lord added daily to them such that needs to be saved. In Acts 4: 42, Acts 4: 32 and Acts 4: 34-37, it is described in terms of fellowship. Believers continued to meet and break bread together, fellowshipping, and praising God together. and the Lord added to their numbers daily those who were being saved (Cotton III, 2006). 


\section{Effect of Church Conflicts on Church Growth}

According to Singer and Small (2008), conflicts is defined as violent disputes pitting two individuals or groups or nations. Heidelberg Institute for International Conflict Research (HIIK, 2005) defined conflicts as an opposing of interests. Thus, this is positional variances regarding some values and involving more than one party including groups, organized groups, states, and organizations with the aim of pursuing their benefits to succeed in their cases.

Despite the establishment and growth of Pentecostal churches all over Kenya, they are punctured by conflict. Kamau (1994) asserts that there are many cases of conflicts in Pentecostal churches, usually followed by splits which negatively affect church growth. The conflicts usually subdue the efforts put forth to resolve them. According to Gathuki (2015), there were several Pentecostal churches that had been established in Kiria-ini town before CCI was established. Some of these churches were the Gospel Outreach, Revival and Hope, Deliverance Church, United Pentecostal Church and Glorious Worship Centre among others. These churches grew and had influence in Kiria-ini town. They attracted many followers from this town and its neighborhood. However, all these churches were later embroiled with conflicts which led to their closure as they lost their members to unending conflicts.

Similar conflicts and subsequent splits in Pentecostal churches are also common in Kenya (Kagema \& Maina 2014). In 2008, the Full Gospel Churches of Kenya (FGCK) was involved in a succession of dispute that broke the sixty-year-old unity which it had enjoyed. This dispute effectively split the church into two factions namely the original FGCK and a faction called Worldwide Full Gospel Churches (Gathuki, 2015). Earlier in the year 2000, similar conflicts had split the Gospel Outreach Church of Kenya forming a new faction called Gospel Revival Centre (GRC). In 2014, the Deliverance Church Nyeri branch, which had about 300 members, got involved in leadership conflicts which split it into two. A large group of members led by the deputy pastor left this church and established a church called Prime Ministry International (PMI) (Gathuki, 2015).

Leadership wrangles is a leading cause of conflict in churches today (Awojobi, 2011). Leadership conflict is the vigorous struggle or may include disorderly fight with the aim of occupying a leadership position or post by whatever means possible which is contrary to the accepted norm or laid down rules/procedure or standard. Put differently, it is a desire to ascend to leadership by "fire or force" or "do or die" against the will of majority. Some people in the church have used diabolical means to take over a given office.

Various examples can be given for churches that have undergone church conflict. For instance, the Church of God Mission under Archbishop Benson Idahosa experienced leadership conflict immediately after his demise 
(Awojobi, 2011). This was after the ordination of his wife, Margaret Idahosa, as his successor even after numerous protests. In protest, some pastors and bishops under this ministry started their own because they were not satisfied with the choice of the wife as their leader (ibid). In another instance, in 2010, a case was filed in the Federal High Court, Lagos as two pastors Olusheye and Akintola were fighting to succeed Pastor E. H. Olusheye as the head of Christ Apostolic Church worldwide (Awojobi, 2011).

According to Haugk (2008), Sande (2004) and Donovan (2006), church conflicts are the major cause of member mobility as people move back and forth from one church to the other never to settle as they seek spiritual satisfaction and a place to belong. Thus, the congregation gets into a state of mobility and change. This mobility exposes Pentecostal Christians to abuse by church leaders who in most cases exploit them financially because they are desperate and are looking for identity. These scholars further observe that many of these members may not know the source of the problem and often hope that such conflicts will be resolved. However, when the situation gets worse to the extent of splitting or closing down a church, such Christians become emotionally unstable and may not trust any other church leader again.

Ansre (1997) noted that personal animosities have also been found to cause family division and loss of property. For instance, the division of the Evangelical Presbyterian Church resulted in the closure of the church buildings and disruption of the church services. Awedoba (2009) writes that in the absence of peace and unity, the development is retarded. Conflicts in most cases lead to the destruction of personal property or even church properties, personal harm, and the sense of uncertainty remains tall. In such an environment of conflict, development of the church is unlikely until peace returned. During the time of conflict, church members take sides and confrontation with opposing sides, and it sometimes turns physical.

\section{Research Design}

The study was based on theological perspective in which it is believed that the Bible is inspired by the Holy Spirit as 2 Timothy 3:16 puts it and thus accepted as the authoritative word of God (De Klerk \& De Wet, 2013, p.300; De Klerk \& Van Rensburg, 2005, p.3). This was a qualitative study which makes use of a phenomenological approach to gather relevant data.

\section{Target Population}

Consequently, the target population of this study was made up of church leaders of position of influence (leaders that offer direction to the church and/or lead a church ministry) and members who have been in the four churches for at least two years, drawn from the churches of FGCK, WGCK, PEFA, and KAG in Nairobi. 


\section{Sample Size and Sampling Techniques}

The study used both probability and non-probability sampling techniques. Purposive sampling method was used to sample the church leaders in the influential positions (i.e., leaders that direct and/or lead a church ministry) of the selected churches according to the church leadership structure espoused by each of the four selected churches, namely: FGCK, WGCK, PEFA, and KAG. The leaders in the selected churches who had served their churches during the period between 2008 and 2019, which is the period when the FGCK and the WGCK experienced conflict and the subsequent split, were interviewed. Secondly, the researcher employed stratified sampling in which the samples were drawn from the strata to ensure that a fair representation of the sample is arrived at. The study used proportionate stratified sampling to select equal number of units from each stratum. Having stratified the population into four levels, the total number of respondents was 84 respondents, comprising of 12 pastors, 24 church elders, and 48 other leaders. The selection formed a fairly acceptable representative sample (crosssectional representation) of the whole population from whom credible data was acquired.

\section{Data Collection}

The study conducted the empirical research through qualitative research and by abiding by the principles and guidelines governing qualitative research. For instance, the study employed interview method due to its ability to describe the participant's life experiences focusing more on the interpretation of the meaning of the described phenomenon (Omery, 1983; Kvale, 1983). This study chose the semi-structured interview method because it covered a raft of questions. Besides, the study also encouraged the interviewees to freely discuss the effect of conflict on church growth. The open-ended questions allowed the study to adjust the questions depending on the participants group. Various notes including personal notes regarding the experiences of the researcher especially in the process of interview, methodological notes of the research process and observational notes of participants, both verbal and non-verbal expression, were taken.

\section{Data Analysis}

Interview transcripts and written notes were analyzed using the constant comparative method whereby line, sentence, and paragraph segments of the interviews and field notes were reviewed to decide what codes fit the concepts suggested by the data. Each code was constantly compared to all other codes to identify similarities, differences, and general patterns. After organization into themes, the data was analyzed thematically using content analysis. To avoid researcher biasness during the interpretation and the overall 
research process, the responses from the field recorded and the transcript was coded by an independent coder.

\section{Findings}

\section{Age of the Respondents}

The results presented in Table 4.1 show that most of the pastor respondents $(83.3 \%)$ were aged 41 years and above. The youngest pastor was from KAG. Most of the church elders (14.5\%) were equally aged 41 years and above.

Table 4.1. Distribution of Respondents by Age

\begin{tabular}{|l|l|l|l|}
\hline & Pastors & Church elders & Other leaders \\
\hline 25-30 years & $0(0.0 \%)$ & $2(2.9 \%)$ & $5(7.2 \%)$ \\
\hline 31-40 years & $1(1.4 \%)$ & $5(7.2 \%)$ & $17(24.6 \%)$ \\
\hline 41-50 years & $8(11.6 \%)$ & $6(8.7 \%)$ & $14(20.3 \%)$ \\
\hline 51-60 years & $2(2.9 \%)$ & $3(4.3 \%)$ & $4(5.8 \%)$ \\
\hline 61 years and above & $1(1.4 \%)$ & $1(1.4 \%)$ & $0(0.0 \%)$ \\
\hline Total & $12(17.4)$ & $17(24.6)$ & $40(58.0)$ \\
\hline
\end{tabular}

\section{Duration in the Church}

The results in Table 4.2 show that none of the pastors and church elders have been in their respective churches for less than five years. Five pastors (7.3\%) have been in the church for between 11 years to 15 years, four (5.8\%) have been in the church for between 16 years to 20 years, and two $(2.9 \%)$ of the pastors have served for more than 20 years. Most of the church elders ( 8 , $11.6 \%$ ) have been in the church for between 16 years to 20 years, while 4 (5.8\%) have been in the church for between 11 years to 15 years. As for other leaders, $13(18.8 \%)$ have been in the church for between 16 years to 20 years.

Table 4.2. Duration in the Church

\begin{tabular}{|l|l|l|l|}
\hline & Pastors & Church elders & Other leaders \\
\hline Less than 5 years & $0(0.0 \%)$ & $0(0.0 \%)$ & $3(4.3 \%)$ \\
\hline $5-10$ years & $1(1.4 \%)$ & $2(2.9 \%)$ & $6(8.7 \%)$ \\
\hline $11-15$ years & $5(7.3 \%)$ & $4(5.8 \%)$ & $11(15.9 \%)$ \\
\hline $16-20$ years & $4(5.8 \%)$ & $8(11.6 \%)$ & $13(18.8 \%)$ \\
\hline 21 years and above & $2(2.9 \%)$ & $3(4.3 \%)$ & $7(10.1 \%)$ \\
\hline Total & $12(17.4 \%)$ & $17(24.6)$ & $40(58.0)$ \\
\hline
\end{tabular}




\section{Participated in Leadership Position in the Church}

All the respondents in all the churches under study have participated in church leadership. Most have served in more than one leadership positions. For instance, four of the pastor respondents, two from Worldwide Gospel Church of Kenya and two from the Full Gospel Churches of Kenya, stated that they served as church elders before being pastors. Other two pastors (both from the Worldwide Gospel Church of Kenya) were once departmental leaders, then elders and pastors. Three pastors, two from Kenya Assemblies of God and one from PEFA, noted that they have been in the pastoral positions all through. All the elder respondents noted that they were once leaders in the departments and other ministries in the church.

\section{Duration in the Leadership Position}

According to Table 4.3, nearly all the pastor respondents have been in the leadership position for more than 10 years. This is nearly the same for the church elders as only two have been in the leadership positions for at most ten years. However, for the other leaders, 7 (10.2\%) have been in the leadership positions for less than five years while $13(18.8 \%)$ have been in the leadership positions for between 5 years to 10 years.

Table 4.3. Duration in the Church Leadership Position

\begin{tabular}{|l|l|l|l|}
\hline & Pastors & Church elders & Other leaders \\
\hline Less than 5 years & $0(0.0 \%)$ & $0(0 \%)$ & $7(10.2 \%)$ \\
\hline 5 - 10 years & $0(0.0 \%)$ & $2(2.9 \%)$ & $13(18.8 \%)$ \\
\hline $11-15$ years & $2(2.9 \%)$ & $5(7.2 \%)$ & $11(15.9 \%)$ \\
\hline $16-20$ years & $4(5.8 \%)$ & $6(8.7 \%)$ & $7(10.2 \%)$ \\
\hline 21 years and above & $6(8.7 \%)$ & $4(5.8 \%)$ & $2(2.9 \%)$ \\
\hline Total & $12(17.4 \%)$ & $17(24.6 \%)$ & $40(58.0 \%)$ \\
\hline
\end{tabular}

\section{Church Growth}

\section{Description of Membership}

Most pastors described the growth of the membership of their churches as gradual with challenges, meaning that the membership has been growing though at a slower pace. This was particular with one respondent who described their church membership as fluctuating because people come and go. Most of the Church elders described the membership of the church as small. Some respondents explained that for a long time, their church has had an average of 40 members while in another church the membership is 65 members. Another respondent described the membership of their church as low but noted that they can see the growth in various groups. Other respondents noted that their church has experienced growth in terms of membership, and that their churches have recorded remarkable increase in membership. One of the respondents under this category indicated that they 
have a membership of about two hundred and about fifty children. Other members described their membership to be below average noting that their church has experienced minimal growth in the recent years.

\section{Frequency of New Members Joining the Church}

The other measure of the church growth was the extent the church received new members. According to findings, some respondents said they often receive new members joining their church like on a weekly basis or in every worship service. Another respondent noted that despite the fact that they receive new members every Sunday who expressed their willingness to join the church, they never stay for long as they leave for various reasons which one of the respondents described as an urban center problem.

\section{Members Participation in Evangelism}

According to respondents from PEFA church, the church has a program for reaching out to the lost every third Sunday of the month and, therefore, the members participated in preaching to the lost. The KAG respondent said that the church has a program where members are trained on evangelism and engage in missions. Other respondents stated that the church had evangelistic team which organizes the church for the activity of reaching out to the lost with the gospel of Jesus. However, a few respondents noted that this was not very common as they rarely did it. When asked whether this was done on individual basis, the respondents overwhelmingly said that this was rare as people waited for the church to organize it for them to take part in. However, a few members participated in the activity as a sign of spiritual growth.

\section{Church Encouraged Members to belong to Fellowships}

According to some respondents, every member of their church is encouraged to join a fellowship where they reside. One respondent noted that the pastor usually reminds the church that it is important for one to belong to fellowship as it was only through the fellowship that people get encouragement from one another through testimonies and prayers. Visitation is also encouraged. Other members noted that through the church's communication channels, the members are encouraged to identify a fellowship where they will be attending. The study, however, established that very few people actually attend fellowships. Various reasons given for lack of attending include work, children among others. This shows that in this area, the church growth may be described as low. 


\section{The Nature of Conflicts \\ Church Experienced Conflict among Leaders}

Most of the respondents indicated that indeed their churches had experienced conflict among their leaders, particularly at the national level, mainly among the pastors and the bishops. The respondents explained that conflict arose when leaders were not contented with the running of the church. According to another respondent, the conflict was minor since it was just among the departmental leaders. Another respondent noted that the conflict was between the ministry leaders particularly the praise, worship, and intercessory team.

\section{Description of Conflict that Happened}

The respondent noted that the conflict was as a result of the pastors and bishops fighting for power and control over the church. One respondent explained that the conflict in their church happened because some of the church leaders were undermining the pastor's vision while there were those who were in support of the pastor. For instance, a respondent said:

"The leader sabotaged the church project and was not participating in any church contributions but was instead inciting members to stop supporting or giving to the church, which caused major split in the church."

Another respondent noted that some leaders were simply against the pastor and thus were inciting the members or the congregation to rebel against the pastor. The study established that, according to some respondents, the conflict ensued when it was revealed that there were some leaders who were revealing the secrets of members who had gone to seek counseling from them. The study further stated that there was conflict because some leaders felt that they were left out when certain decisions were made in the church which caused factions in the church. Respondents explained that the conflict was as a result of differences in some biblical principles or doctrines with regard to church leadership.

\section{Effects of Conflict on Church Growth Effects on Church Members}

According to majority of the respondents, the conflict among the leaders caused division and/or split among the church members. Respondents noted that the conflict retarded the church growth as people stopped participating in church activities such as fellowships, church giving, gatherings, and they became disloyal to their leaders. The study established that the conflict resulted into unending wrangles in the church leading to divisions in which the church was divided into factions - others are pro-pastor 
while others were against the pastor. The study established that conflict results in stagnation, reduction of members' commitment, and the failure of church project. The effect of conflict on members was in three ways, namely: financially as some members failed to give, spiritually as the church activities such as corporate prayers and church fellowships declined, and numerically as the numbers of those attending fellowships and worship services declined. Another respondent noted that the conflict caused misunderstanding and division among the members. He went on to note that the conflict brought bitterness and enmity among the members, which affected the members' spirituality. The respondents from the churches which experienced conflicts largely blamed the conflict for the non-settling of new members in the church, which they pointed to have negatively affected the church growth.

\section{Caused Members to Leave Church}

According to some respondents, some members left church because of the conflict. The respondents went ahead to explain that these members joined other churches around. A respondent explained that he knew one member who went back to the Roman Catholic Church. One of the respondents explained:

"The conflict had a bad effect on some of our members. I know of a few of our people who quit the church and are no longer attending any church as they have denied the faith."

However, a few respondents stated that the conflict did not in any way cause members to leave the church. He explained that the pastor handled the conflict in a more mature manner that left the church even more cohesive.

\section{Effect of Conflict on the Spirituality of Church Members}

According to some members, the conflict impacted negatively on the spirituality of the members as some members became bitter to the extent of losing their tempers and almost went physical, which is contrary to the scriptures in Hebrews 12: 14-15 "...that no root of bitterness springs up and causes trouble, and by it many become defiled". Respondents further stated that many people were greatly affected spiritually as others stopped going to church all together.

Some respondents said that conflict in the Pentecostal churches was common especially among the leaders fighting over the control of the church. They went ahead to note that this was the major cause of split in majority of the Pentecostal churches during which the numerical growth of the church is affected as different factions go with section of the members and, sometimes, the members quit the church or join other neighboring churches. According to some members, church conflict has resulted in many church divisions, which has hindered the growth and progress of the church because of transitions members have to go through. Two respondents noted that conflicts in the 
church make people stop coming to church. Respondents attributed the church conflict to the selfishness of some leaders which have negatively affected the growth of the church as the church has lost many members due to conflict.

\section{Conflict Resolution}

According to the results, most respondents stated that the church went into prayer and fasting, and things went back to normal. Some respondents stated that their pastor was transferred and the one replaced him made changes in the leadership of the church which calmed down the conflict. The pastor through mediation of other church leaders from other churches led the church members through the reconciliation process where people asked each other for forgiveness and the church went back to normalcy. Another respondent stated that since the conflict arose among the leaders, it was the leaders who sat and resolved the issues and things went back to normalcy.

\section{Discussion}

The study established that even though some churches experienced growth, the growth was with some difficulty as there were fluctuations particularly in membership. There were, however, some churches that experienced steady growth. This growth is mainly the numerical growth as they experienced increase in numbers of its members. This was also in accordance with the early church in Acts 2:46. The other areas of growth included participation in church activities such as prayer without ceasing, evangelism and witnessing, and fellowships among others as signs of spiritual growth. These practices were, however, successful only to a moderate extent since not a majority participated in the activities. The study findings that the members participated in church meetings for prayers are in agreement with the views of Kim (2011) who argued that there was a relationship between prayers and church growth. The findings are equally in accordance with Acts 4: 43, Acts 4: 24-30, and Acts 12: 5 which teaches on the need for prayers by Christians as was the case of the early church, i.e., they came together constantly for prayers and were very devoted to prayers.

The study established that while the leaders emphasized the need to belong to the fellowship or cell groups, most members rarely attended these fellowships. However, they were all in agreement that fellowships enhanced church growth. These findings that the members were reluctant in attending fellowship are contrary to the teachings in Acts 4: 42, Acts 4: 32, and Acts 4: 34-37 that records that the believers sold their possession and shared among each other so that everyone had everything in common and were in constant fellowship. The Bible went ahead to note that the believers continued to meet and break bread together, fellowship and praising God together. This aspect is lacking in the studied churches as the fellowships are weak which could be the 
reason for growth challenges as the Bible notes in Acts as quoted by Cotton III (2006) that the believers enjoyed favour of all the people and as this was happening, the Lord added to their numbers daily those who were being saved.

The study established that in nearly all the churches under study, they had experienced conflict: some at local level pitting the pastors and either members or pastor and leaders particularly the elders or just among the church leaders. In other churches, the conflict was at a national level, but cascaded down to the local church level. These conflicts according to the findings negatively affected the growth of the churches as some resulted in members leaving the church and joining other churches or simply quitting the faith all together. The findings that nearly all the churches under study have experienced conflict of some sorts agree with Kamau (1994) who noted that there are many cases of conflicts in Pentecostal churches, usually followed by split, like it was the case of Full Gospel Churches of Kenya in 2008 with splinter group Worldwide Gospel Church of Kenya. The findings also concur with Gathuki (2015) who noted that prior to the establishment of the CCI in Kiria-ini, there were other Pentecostal churches such as the Gospel Outreach, Revival and Hope, Deliverance Church, United Pentecostal Church, and Glorious Worship Centre among others which grew and attracted many followers within the town and its environs. Later, they noted that all the churches were embroiled with conflicts which resulted into split and even closure of some. The findings that the conflict made some members quit church agree with Donovan (2006) who noted that hopelessness and despair set in among the affected in case of a church conflict. As a result, some would start wondering from church to church to find a place to identify with. He further noted that church conflict is a source of mistrust between the leaders and believers, leading to formation of factions in the church and resulting in incessant fighting. These findings also agree with Haugk (2008), Sande (2004), and Donovan (2006) who noted that church conflicts are the major cause of member mobility as people move back and forth from one church to the other never to settle as they seek spiritual satisfaction and a place to belong. Thus, the congregation gets into a state of mobility and change. These have a direct effect on the growth of the church.

\section{Recommendations}

The Pentecostal churches in Kenya should develop strong conflict resolution mechanism in order to avoid church conflicts. The church leaders should be accommodative to all other leaders so as to avoid exclusion from the running of the church. They should avoid running the church as sole proprietors or rather like a personal property. The church should adopt strategies that will bring the members together rather than scatter them and, as such, conflict should be avoided at all cost. 


\section{References:}

1. Anderson, A. H. (2013). To the Ends of the Earth: Pentecostalism and the Transformation of World Christianity. . New York: Oxford University Press.

2. Asamoah-Gyadu, J. K. (2005). African Charismatics: Current Developments within Independent Indigenous Pentecostalism in Ghana. Leiden: E. J. Brill.

3. Atoyebi, P. O. (2010). From Stagnation to Revitalization: A Story of Select Turnaround Churches in the Urban Cotext of Nairobi, Kenya. Thesis of North-West University.

4. Best, J. W., \& Khan, J. V. (2006). Research in education (10th ed.). Boston: Pearson Education, Inc.

5. Creswell, J. W. (2003). Research Design: Qualitative, Quantitative and Mixed Methods Approaches (2nd ed.). London: Sage Publications Ldt.

6. Folarin, G. O. \& Adelakun, A. J. (2016). Multi-dimentional Approach to Crisis Management in the Church. European Scientific Journal, 12(23), 270-288.

7. Gathuki, D. M. (2015). Conflicts in Pentecostal Churches: The Case of Christian Church Internatioal, Kiria-ini Town Murang'a County, Kenya. Unpublished Thesis of Kenyatta University.

8. Haugk, C. (2008). Antagonists in the Church: How to Identify and Deal with Destructive Conflict. Minneapolis: Augsburg Books Publishers.

9. Hollenweger, W. J. (2007). Pentecostalism: Origins and Developments Worldwide. Peabody: Hendrickson Publishers.

10. Jando, F. S. (2014). Growth and Expansion of Pentecostal Churches in Tivlans 1975-2005. PhD Thesis on University of Nigeria, NSUKKA.

11. Kagema, D. N., \& Maina, M. W. (2014). Causes of the New Charismatic Movements (NCMS) in Kenya. Global Journal of Arts Humanities and Social Sciences, 2(2), 35-44.

12. Kamau, M. W. (1994). Leadership Conflicts in the Africa Independent Pentecostal Church of Africa with Particular References to Gitothua. Nairobi: M.A. Thesis Kenyatta University.

13. Lamb, A. M. (2016). Exploration into Small, Rural, Declining, Near End of Life-Cycle Church Turnaround in the Wesleyan and United Methodist Church. Thesis of Asbury Theological Seminary.

14. Onyima, B. N. (2013). Understanding Proliferation of Pentecostal Churches: The Role of Intra-church Social Conflicts and Religious Freedm. Retrieved December 7, 2019, from http://papers.ssrn.com/sol3/papers.cfm?abstract_id2327762. 
15. Oslon, D. T. (2008). The American Church in Crisis. Zondervan: Grand Rapids, MI.

16. Osmer, R. R. (2008). Practical theology: an introduction. Grand Rapids: William B Eerdmans Publishing Co.

17. Parsitau, D. S. (2014). The Civic and Public Roles of Neo-pentecostal Churches in Kenya (1970-2010). Unpublished Thesis of Kenyatta University.

18. Parsitau, D. S., \& Mwaura, N. J. (2010). "Gospel without Borders" Gender Dynamics of Transbational Religious Movements in Kenya and the Kenyan Diaspora. In A. A. Spickard, Religious Crossing Boundaries: Transnational Religious Dynamics in Africa and the New African Diaspora. Leiden Netherlands: Koninklijke.

19. Sande, C. (2004). The Peacemaker: A Biblical Guide to Solving Personal Conflict. Grand Rapids, Michigan: Baker Books Publishers.

20. Show, M., \& Gitau, W. M. (2016). African Megachurches and Missions: Mavuno Church, Nairobi, and the Challenge of Accountability. In D. Baker, Megachurch Accountability in Missions: Critical Assessment through Global Case Studies. New Haven: OMSC Publications. 